\title{
HR at a crossroads
}

Dave Ulrich University of Michigan, USA; The RBL Group, USA

\begin{abstract}
No one doubts the unprecedented pace of change in today's business world. For organizations to succeed in this changing world, they need to rely even more on HR insights. The HR profession is at a crossroads. On the one hand, it can remain focused on providing services that produce more efficient organizations. Or, it can respond to the opportunities of change and create ever more market value. To create market value, HR can deliver innovative talent, leadership, and organization solutions. This article lays out specific ways to improve HR outcomes. To make these solutions happen, HR will need to redefine how it is organized and demonstrate new HR competencies. Asian markets and organizations are a unique setting for HR to respond to new opportunities and generate market value.
\end{abstract}

Keywords: capability, HR competencies, HR crossroads, HR market value, HR organization, HR value added, leadership, talent

\footnotetext{
Key points

$1 \mathrm{HR}$ is not about HR, but about delivering business value.

2 To deliver value, HR's perspective should be outside in, starting with and serving customers and investors.

3 To deliver value, HR should deliver three outcomes: talent, leadership, and capability.

4 To deliver value, HR should transform the function and upgrade HR professionals.
}

In a world of increased volatility, uncertainty, complexity, and ambiguity (VUCA), HR issues matter more than ever (Yeung and Ulrich 1990). The increased relevance of HR functions, practices, and professionals to stakeholder outcomes makes this both a great and a risky time to be in HR. The good news is that HR professionals have more opportunity to influence business success. The United States' Conference Board's 2014 survey of global CEO challenges ranked human capital issues as the number one challenge (The Conference Board 2014). We have also found that the leadership profile of successful CEOs matches the leadership profile of effective CHROs (Ulrich and Filler 2015), and that $\mathrm{HR}$ issues are increasingly a part of firm valuation by thoughtful investors (Bassi,

Correspondence: Professor Dave Ulrich, Rensis Likert Professor, Ross School of Business, University of Michigan, USA; e-mail: dou@umich.edu

Accepted for publication 16 December 2015. 
Creelman and Lambert 2014; Ulrich 2015a, b, c). Estimates are that about one-third of the issues discussed at the board level are HR related (e.g. succession planning, talent review, executive compensation, governance, strategy execution, ethics, and culture).

But it is also a riskier time to be in HR because of increased expectations. HR professionals are under more scrutiny than ever to respond as their role takes on a higher profile (Ulrich and Dulebohn 2015). When understudies become the lead in a play, when backup players enter a game, or when employees become owners of a company, opportunities for both success and failure increase. Likewise, as HR professionals shift from policy administration, employee transactions, and functional excellence to business outcomes, they will have more and unique opportunities available to have influence.

Indeed, HR is at a crossroads. We believe that HR can rise to this occasion and meet these higher expectations (Lawler and Boudreau 2015). As the role and function of HR continue to evolve, the business world's perspectives on the field will need to evolve with them. To respond to the new HR opportunities, many HR legacy mindsets that may have been true in the past need to evolve to modern realities (see Table 1).

These transitions are particularly poignant in Asia where global economic trends are intensified (Nankervis et al. 2015; Rowley and Redding 2012). With the rapid growth in

Table 1 Historical myths and modern realities for HR

\begin{tabular}{|c|c|}
\hline Historical HR myths & Modern HR realities \\
\hline $\begin{array}{l}\text { HR professionals go into HR because } \\
\text { they like people. }\end{array}$ & $\begin{array}{l}\text { HR is not just about liking people, but about } \\
\text { understanding and solving people related problems in } \\
\text { organizations. In fact, HR often requires tough people } \\
\text { choices to assure business results. }\end{array}$ \\
\hline $\begin{array}{l}\text { HR professionals don't believe in or } \\
\text { rely on numbers. }\end{array}$ & $\begin{array}{l}\text { HR has relied on data for years; now more than ever } \\
\text { predictive analytics guide HR decision-making. }\end{array}$ \\
\hline $\begin{array}{l}\text { HR professionals want to get 'to the } \\
\text { table' where business decisions are } \\
\text { made. }\end{array}$ & $\begin{array}{l}\text { HR professionals are now invited to the table; the } \\
\text { challenge is knowing what to contribute to stay. }\end{array}$ \\
\hline $\begin{array}{l}\text { HR's customers are the employees in } \\
\text { the company. }\end{array}$ & $\begin{array}{l}\text { HR's customers are the customers of the company; HR } \\
\text { work helps both internal employees and external } \\
\text { customers. }\end{array}$ \\
\hline $\begin{array}{l}\text { HR's measures of success come from } \\
\text { delivering the practices related to HR } \\
\text { (e.g. staffing, training, compensation, } \\
\text { etc.). }\end{array}$ & $\begin{array}{l}\text { HR is about delivering business results; the scorecard of } \\
\text { HR is the business's scorecard. }\end{array}$ \\
\hline $\begin{array}{l}\text { HR is responsible for the organization's } \\
\text { talent, leadership, and capability. }\end{array}$ & $\begin{array}{l}\text { Line managers are the primary owners of talent, } \\
\text { leadership, and culture; HR professionals are } \\
\text { architects who design blueprints and inform choices. }\end{array}$ \\
\hline $\begin{array}{l}\text { HR's primary role is to keep the } \\
\text { organization compliant with laws } \\
\text { and regulations. }\end{array}$ & $\begin{array}{l}\text { Good HR leaders help the organization make good } \\
\text { business decisions that match the risk tolerance (or } \\
\text { appetite) of the organization. }\end{array}$ \\
\hline
\end{tabular}


Asia, increased pace of change, and dramatic competitiveness, Asia is a setting where management of talent (people and individuals)and organization (culture and capabilities) becomes a key to competitiveness. Asia's eastern philosophy also raises the relevance of human resource principles in driving business results (Nankervis et al. 2013; Rowley, Benson and Warner 2004; Yeung, Warner and Rowley 2008). There are many cases where Asian settings are exemplars of modern HR practices (Chakrabarti, Singh and Mahmood 2007; de Waal and Tan Akaraboworn 2013; Danish and Usman 2010; Osman, Ho and Galang 2011). The HR crossroads are important to study so that Asian leaders can recognize these modern realities and appropriately adapt HR practices to respond.

To live up to these modern realities, this essay will review 1) the HR crossroads, 2) the emerging outcomes of HR for talent, leadership, and capability, and 3) HR for HR including governance and competencies.

\section{HR crossroads: content and process}

To respond to these modern realities, HR faces a crossroads with two choices about both content and process. Content choices emphasize where HR will add the most value to the organization. On the one hand, HR value may come from internally focused services, which means managing HR processes more efficiently such as reducing cost per hire per employee. On the other hand, HR value may come from business results, emphasizing how HR delivers shareholder value, customer share, and strategy execution. This crossroads determines how HR professionals define their roles either inside out (who we are) or outside in (who we serve) (Ulrich et al. 2012).

Process choices refer to how HR professionals go about doing their work. Based on work by national security expert Gregory Treverton (2003) and amplified by author Malcolm Gladwell (2011), decisions can be made through puzzle-solving or mystery exploration. In HR today, analytics play an increasing role. Puzzle-solving is being an architect who builds blueprints that guide how to build the right house for the owner. Good architects turn owners' lifestyles into blueprints and eventually residences. Mystery exploration is being an anthropologist who thoughtfully observes the world to discover what people do. Anthropologists find order in chaos; they interpret and organize unrelated issues into patterns that can be explained.

HR architects are puzzle solvers; HR anthropologists are mystery investigators. Puzzlesolving analytics focus on the science of HR, with frameworks, spreadsheets, and analytics. Mystery-seeking analytics focus on the art of HR, with observations, perceptions, and insights. Puzzles focus on answers, mysteries on questions. Puzzles solve problems; mysteries define them. Puzzles offer certainty; mysteries encourage curiosity. Puzzles imply that HR professionals are architects doing design work; mysteries imply HR professionals are anthropologists observing patterns.

Putting the content and process choices together, we can identify four options in the HR crossroads (see Figure 1). 


\begin{tabular}{|c|c|c|c|}
\hline & & $\begin{array}{l}\text { Content: } \\
\text { What we focus on to cre }\end{array}$ & te value \\
\hline & & $\begin{array}{l}\text { Services } \\
\text { - Administrative } \\
\text { processes (e.g. } \\
\text { cost/hire/employee) } \\
\text { - Inside out (who we } \\
\text { are) }\end{array}$ & $\begin{array}{l}\text { Market } \\
\text { - Business results (e.g. } \\
\text { market value, customer } \\
\text { share, strategy } \\
\text { execution) } \\
\text { - Outside in (who we } \\
\text { serve) }\end{array}$ \\
\hline $\begin{array}{l}\text { Process: } \\
\text { How we } \\
\text { focus our } \\
\text { work }\end{array}$ & $\begin{array}{l}\text { Puzzle } \\
\text { - Architects } \\
\text { - Frameworks } \\
\text { - Science } \\
\text { - Analytics }\end{array}$ & $\begin{array}{l}1 \\
\text { How do we better } \\
\text { analyze HR practices? } \\
\text { (e.g. standards for } \\
\text { reporting) }\end{array}$ & $\begin{array}{l}2 \\
\text { How do we link HR to } \\
\text { business results? (e.g. } \\
\text { indices like leadership } \\
\text { capital) }\end{array}$ \\
\hline & $\begin{array}{l}\text { Mystery } \\
\text { - Anthropologists } \\
\text { - Inquiries } \\
\text { - Art } \\
\text { - Questions }\end{array}$ & $\begin{array}{l}\text { 3 } \\
\text { How do we explore new } \\
\text { ways to operate better? }\end{array}$ & $\begin{array}{l}4 \\
\text { How do we sense market } \\
\text { trends that are not yet } \\
\text { understood? }\end{array}$ \\
\hline
\end{tabular}

Figure 1 Choices in the HR crossroads

Often HR future falls into cell 1 where we seek standards and consistency in reporting HR services such as scorecards and standards. More recently, work on linking HR to business results has moved into cell 2 where things like the leadership capital index become mechanisms to define HR value where HR links to external business realities. We envision more work in cell 3 where HR professionals probe new ways to operate better inside the organization. This work might include innovations in thinking about employee engagement/well-being and organization capability/culture. Cell 4 comes when HR professionals co-create outside-in perspectives on how to add value by posing new questions and seeking new answers. With these crossroads in mind, we can look at the outcomes of HR and how they evolve as HR professionals seek to deliver value from the outside in through defining mysteries (cell 3 and 4).

Outside-in thinking means that HR aligns HR practices to customers, investors, and other external community stakeholders. Outside-in HR is based on the premise that the business of HR is the business. Outside-in logic goes beyond the current state of the HR profession, where the focus is on connecting strategy to HR. We now believe that rather than a mirror in which HR practices are reflected, business strategy should be regarded as a window through which HR professionals observe, interpret, and translate external conditions and stakeholder expectations into internal actions.

As HR has shifted to outside-in thinking, the perspective has evolved to value created through serving key external stakeholders and responding to business conditions of change. With their business focus, HR professionals can accurately converse about customers, products, operations and financials, but also help create the right type of organization that sustains market value (Ulrich et al. 2012). 


\section{Outcomes: what unique value does HR contribute to business results?}

With an outside-in perspective, HR professionals offer unique information, insights, and recommendations to deliver competitive advantage. In formal and informal business discussions, each staff group brings unique insights to drive business results: finance talks about economic performance with information about revenues, costs, and financial returns; marketing discusses customers with recommendations on targeting key customers, customer response (e.g. net promoter score), and customer connection; operations makes recommendations and systems, quality, and supply chain. When HR partners in these strategy discussions, we propose that they provide insight, information, and recommendations on talent (people, workforce, human capital), capability (culture, processes, key success factors, systems), and leadership.

\section{Talent}

At the risk of grossly oversimplifying, let me suggest that there is actually a deceptively simple formula for talent that makes people more productive: Talent $=$ Competence $\times$ Commitment $\times$ Contribution (Ulrich 1998). All three elements of this equation need to be considered and integrated to fully manage talent.

Competence means that individuals have the knowledge, skills, and values required for today's and tomorrow's jobs. One company clarified competence as 'right skills, right place, right job, right time'. For example, an emerging trend in the workforce planning domain of competence improvement is to identify key positions and match people to positions. Competence should start outside in by turning customer expectations into the talent requirements for the future. In Asia, we found that bringing the right people into the organization and managing them through the organization were key processes that lead to strategic success (Allen and Ulrich 2013).

Committed or engaged employees work hard and do what they are asked to do, but may be doing the wrong things. With an outside-in focus, committed employees focus attention on work and activities that will deliver value to customers, investors, and communities. Committed employees have an employee value proposition that balances what employees give to the firm with what they get back. Dozens of engagement studies have shown that more committed employees are more productive. Engagement in many Asian companies focuses not only on commitment, but on retention of key employees in key positions. It also is tracked through productivity from existing employees.

Contribution refers less about behavioral engagement and more about emotional connection to the organization. When employees find meaning (sometimes called well-being or growth mindset), they become personally connected to the values of the organization. Their engagement comes from within and ensures over time. In our book Why of work, we identified seven factors that help employees find meaning from work (Ulrich and Ulrich 2011):

1 What am I known for? Discover one's signature strengths and weaknesses that shape an identity. 
2 Where am I going? Determine what matters most to an employee and what gives them a sense of purpose.

3 Whom do I travel with? Learn to build positive teams and relationships.

4 How do I build a positive work environment? Create a positive work setting and culture.

5 What challenges interest me? Help people solve problems that matter to them.

6 How do I respond to disposability and change? Allow employees to learn and grow from their work.

7 What delights me? Help people find joy and fun from work tasks.

With these ideas in mind, HR professionals focused on talent outcomes can raise questions such as:

- To what extent do our employees have the knowledge and skills required to deliver on our expectations for customers, investors, and communities?

- To what extent do we have an employee value proposition that increases commitment and engagement of our employees to the right goals?

- To what extent do our employees find meaning and purpose from their work so that they are self-motivated to accomplish work?

\section{Capability}

In the last 15 to 20 years, the HR profession has been shaped by remarkable work captured in the 'war for talent' (Michaels, Handfield-Jones and Axelrod 2001). To win the war for talent, many of the professionals have built systems for bringing people into the organization (sourcing, having a value proposition), moving them through the organization (development, performance management, engagement), and removing them from the organization (outsourcing) (Allen and Ulrich 2013).

But, in today's business, HR professionals need to establish organizations that leverage individual talent through collective actions. Talent is not enough. The whole organization should be greater than the separate parts. Teams outperform individuals. Individuals are champions, but teams win championships. Some simple statistics show the importance of teamwork over talent:

- In hockey, the leading scorer is on the team that wins the Stanley cup $22 \%$ of the time.

- In soccer, the winner of the Golden Boot (leading scorer) is on the team that wins with World Cup 20\% of the time.

- In basketball, the player who scores the most points is on the team that wins the NBA finals $15 \%$ of the time.

- In movies, Best Movie of the year also has the leading actor (25\%) and actress (15\%) of the time.

Talent matters, but in many cases, organization matters more. 
Let me propose a three-step process (summarized in Figure 2) for HR professionals to bring discipline to moving from war for talent to creating victory through organization (Ulrich 2015a, b, c).

In step 1, organization capabilities represent what the organization is known for, what it is good at doing, and how it allocates resources to win in its market. Organizations should be defined less by their structure and more by their ability to establish the capabilities required to win - that is, to serve customers in ways that competitors can not readily copy. Organization capabilities might include ability to respond to or serve customers, drive efficiency, manage change, collaborate both inside and outside, innovate on products and business model, access information, and establish the right culture. HR professionals can facilitate capability audits to determine if the organization has prioritized the right capabilities to win (Ulrich 1997; Ulrich and Smallwood 2004).

In step 2, the culture becomes a key capability. Using the outside-in perspective, an organization's culture is less about events (rituals, symbols, or artifacts) or patterns (values, norms, expectations), and more about an identity (reputation of the firm in the mind of key external stakeholders made real to employees). The right culture takes what the organization should be known for by key customers and uses this external identity to shape internal thought and action (Ulrich et al. 2009). This template for culture change suggests that a firm's culture changes when its customer promises change, that culture should vary across businesses to the extent that customer promises vary, and that culture ultimately creates value through increased customer share. HR professionals can audit the extent to which an organization has the right culture.

In step 3, management actions can be identified and implemented to create and sustain the desired culture. My colleagues and I have classified these actions into intellectual, behavioral, and process agendas. Intellectual agendas ensure that managers create a shared culture inside and outside the organization; behavioral agendas show the extent to which all employees behave consistently with the desired culture; and process agendas institutionalize the culture through management practices.

In business dialogues, HR professionals can be the architects (defining the logic and blueprint) and anthropologists (interpreting the right pattern) of capability by raising the following questions:

- To what extent have we defined our culture from the outside in, making sure that our external firm brand becomes the basis for our internal ways of thinking and acting?

- To what extent have we created a disciplined process of evaluating and transforming our culture?

- To what extent do our management actions (intellectual, behavioral, and process agenda) reflect our desired culture?

\section{Leadership}

Ultimately, leaders bring together both individuals and organizations to solve customer problems. But, there is a difference between leaders and leadership. The term 'leaders' refers to individuals who have unique abilities to guide the behavior of others. Leadership 


\begin{tabular}{|c|c|c|c|c|}
\hline Summary logic & $\begin{array}{l}\text { Key question and } \\
\text { focus }\end{array}$ & $\begin{array}{l}\text { Previous } \\
\text { research }\end{array}$ & $\begin{array}{l}\text { Audits that can be } \\
\text { done }\end{array}$ & $\begin{array}{l}\text { Analogue with } \\
\text { individual }\end{array}$ \\
\hline Capability & $\begin{array}{l}\text { What is the } \\
\text { organization good } \\
\text { at doing and what } \\
\text { should it be } \\
\text { known for? } \\
\text { Competitive } \\
\text { differentiators. }\end{array}$ & $\begin{array}{l}\text { Resources } \\
\text { Strategic } \\
\text { capabilities } \\
\text { Core } \\
\text { competencies }\end{array}$ & $\begin{array}{l}\text { What do we have to } \\
\text { be known for and } \\
\text { good at to win? This } \\
\text { should be tightly } \\
\text { linked to strategy. } \\
\text { Measure the extent } \\
\text { to which priorities } \\
\text { are shared about } \\
\text { capabilities required } \\
\text { to win. }\end{array}$ & $\begin{array}{l}\text { What is my } \\
\text { personality? } \\
\text { We each have a } \\
\text { personality that } \\
\text { can be dissected } \\
\text { into five core } \\
\text { personality traits } \\
\text { based on what } \\
\text { comes naturally to } \\
\text { us. }\end{array}$ \\
\hline Culture & $\begin{array}{l}\text { How do we shape } \\
\text { the right patterns } \\
\text { that will enable us } \\
\text { to win? } \\
\text { How the } \\
\text { organization } \\
\text { works: event, } \\
\text { pattern, identity. }\end{array}$ & $\begin{array}{l}\text { Competing } \\
\text { values } \\
\text { Organization } \\
\text { types } \\
\text { Organization } \\
\text { health }\end{array}$ & $\begin{array}{l}\text { Cultural audit: } \\
\text { Do we have the } \\
\text { right patterns for } \\
\text { thinking and } \\
\text { behaving? } \\
\text { Measure the clarity } \\
\text { and accuracy of the } \\
\text { culture. }\end{array}$ & $\begin{array}{l}\text { What habits that } \\
\text { my lifestyle and } \\
\text { identity? } \\
\text { We each have } \\
\text { habits or routines } \\
\text { that determine who } \\
\text { we are. }\end{array}$ \\
\hline $\begin{array}{l}\text { Management } \\
\text { action 1: } \\
\text { Intellectual } \\
\text { agenda }\end{array}$ & $\begin{array}{l}\text { Create a clear } \\
\text { message about } \\
\text { the desired culture } \\
\text { to share inside } \\
\text { and outside. }\end{array}$ & $\begin{array}{l}\text { Shared } \\
\text { mindset or } \\
\text { shared values }\end{array}$ & $\begin{array}{l}\text { Unity audit: } \\
\text { Do we have a } \\
\text { shared culture? } \\
\text { Do we make } \\
\text { recognize implicit } \\
\text { our assumptions? } \\
\text { Measure unity of } \\
\text { culture and clarity of } \\
\text { assumptions. }\end{array}$ & $\begin{array}{l}\text { What are my } \\
\text { thought patterns } \\
\text { (schema)? }\end{array}$ \\
\hline $\begin{array}{l}\text { Management } \\
\text { action 2: } \\
\text { Behavioral } \\
\text { agenda }\end{array}$ & $\begin{array}{l}\text { Turn culture } \\
\text { identity into } \\
\text { employee actions. }\end{array}$ & Climate & $\begin{array}{l}\text { Behavioral audit: } \\
\text { Do employee } \\
\text { behaviors link to the } \\
\text { culture? } \\
\text { Measure behavior } \\
\text { alignment and } \\
\text { change. }\end{array}$ & $\begin{array}{l}\text { What are my daily } \\
\text { actions? (calendar } \\
\text { test) }\end{array}$ \\
\hline $\begin{array}{l}\text { Management } \\
\text { action 3: } \\
\text { Process } \\
\text { agenda }\end{array}$ & $\begin{array}{l}\text { Create, shape, } \\
\text { and reinforce } \\
\text { culture through } \\
\text { management } \\
\text { practices. }\end{array}$ & $\begin{array}{l}\text { Systems, e.g. } \\
\text { - } 7 \mathrm{~s} \\
\text { - STAR } \\
\text { - High- } \\
\text { performing } \\
\text { work system } \\
\text { Organization } \\
\text { processes }\end{array}$ & $\begin{array}{l}\text { Process or system } \\
\text { audit: Do we have } \\
\text { processes that } \\
\text { reinforce and } \\
\text { embed the culture? } \\
\text { Measure process } \\
\text { alignment and } \\
\text { change. }\end{array}$ & $\begin{array}{l}\text { How do my } \\
\text { emotions shape } \\
\text { my experience and } \\
\text { sustain my desired } \\
\text { routines? }\end{array}$ \\
\hline
\end{tabular}

Figure 2 Three dimensions of competitive organization: capability, culture, management action 
refers to an organization's capacity to build future leaders. An individual leader matters, but an organization's collective leadership matters more over time. Looking forward, HR professionals will need to not only help individual leaders be more effective through coaching, 360 feedback, and individual development plans, but also build leadership depth.

Asian organizations lead the leadership agenda because they focus on building leaders throughout the organization (Rowley and Ulrich 2012; Ulrich 2010; Ulrich and Sutton 2011). They also recognize that effective leadership melds the best of the West and East. Leaders from the West assigned to work in Asian organizations need to be aware of their biases and to adapt to eastern philosophies. Asian leaders who fall prey to only doing things the 'eastern way' will not be able to respond to global pressures. Asian leaders who give in to the 'western way' will lose sight of their heritage and be inattentive to their cultural uniqueness. Operating in Asia requires managers to understand the often hidden 'rules of the game', the role of factors such as nurturing relationships and connections (Chinese guanxi, Japanese kon, Malay orang delam, Korean inmaek and Vietnamese quan he), age and 'face', and also being comfortable with uncertainty and ambiguity. This type of management behavior melds East and West and allows leaders to produce unique outcomes (Rowley and Ulrich 2013).

The outcome of effective leadership is not only employee engagement and organization goal achievement, but shareholder (debt or equity) confidence. In recent work, I proposed a leadership capital ratings index (like the Moody's credit worthiness index) that could be used to define effective leadership (Ulrich 2015a, b, c). This index would have two dimensions, or domains: individual and organizational. Individual refers to the personal qualities (competencies, traits, characteristics) of the key leaders in the organization. Organization refers to the systems (often called human capital) these leaders create to manage leadership throughout the organization and the application of organization systems to specific business conditions. Using these two domains, previous leadership and human capital work may be synthesized into a leadership capital index that investors and others can use to inform their valuation decisions and HR professionals to enhance their impact. By using a leadership capital index, the requirements of effective leaders could be defined and clarified from the outside in.

In business settings, HR professionals may prod a discussion of the right leadership with questions such as:

- To what extent do we recognize the importance of collective leadership in reaching our goal?

- To what extent do we create a leadership brand that defines how leaders inside our company better serve external stakeholders?

- To what extent do we regularly assess our leadership capability to discover areas of strengths and weakness?

- To what extent do we seriously invest in developing future leaders who will respond to future business requirements? 


\section{HR for HR: how can HR invest in HR?}

HR for HR means that HR professionals apply to their own function the knowledge and tools they apply to their organizations. This means building the right HR organization by making sure that the HR department aligns with the business organization. It means investing in the HR professionals to ensure that they respond to future opportunities.

\section{HR governance: relationships more than roles}

Debates continue about how to organize HR departments. Should HR work be centralized (functionally driven across an enterprise), decentralized (uniquely applied to each business), or some combination (shared services)? With others, I have tried to define the right roles that HR professionals play to have an optimal HR operating model. We have proposed that the HR structure should match business strategy and structure. In many cases, where a diversified business strategy has a divisional, networked, matrix, hybrid, or allied structure, we have proposed an HR operating model with service centers focused on technology-enabled transaction capability, centers of expertise with deep specialized HR knowledge and insight, embedded HR generalists who adapt HR services to deliver business needs, and corporate HR leaders who set overall policy. With good intent, many keep tweaking these HR roles to help the HR department and HR professionals deliver increased business value (Ulrich and Grochowski 2012; Ulrich, Younger and Brockbank 2008).

In our research on 12 key foci of an HR department, we found that 'Has clear roles and responsibilities for each of the groups within HR (e.g. service centers, centers of expertise, embedded HR)' ranks as among the best done but least influential on business impact. On the other hand, 'Connects HR activities to external stakeholder expectations (e.g. customers, investors)' and 'tracks and measures the impact of HR' were the two activities with highest business impact and least well done.

As I have pondered these findings and heard the ongoing debates about improving HR operating models, I have come to the conclusion that upgrades to the HR operating model will come less from roles defined on organization charts and more from improved relationships. Imagine a family that is not getting along. They try to get along better by buying new appliances, chairs, and couches. Most of us realize that new furnishings won't help a family get along better. In HR, new HR tools and technologies are unlikely to improve the operations within the HR department. Then, the dysfunctional family remodels their house or buys a new house with more and larger rooms. Again, most realize that new floor plans won't necessarily help a family get along better. Likewise, merely changing boxes on organization charts won't help HR professionals work better together.

For families to function better, they need to learn to belong, to focus on relationships more than roles. For HR operating models to deliver more value, once the basic roles are satisfied (e.g. matching HR structure to business strategy and structure), maybe we should focus more on relationships than roles.

Many have studied what makes relationships work better in friendships, couples, families, and communities. For example, John Gottman, a relationship scholar, has been able to 
predict with over $90 \%$ confidence which couples will stay together. Synthesizing relationship research, let me propose six principles that, when applied, may improve the HR operating models more than debates about roles (Ulrich 2015a, b, c).

\section{Share a common purpose}

Partners in a relationship have different roles to play, but they succeed when they realize that they are stronger together than apart because they have superordinate and binding goals (e.g. raising children). Couples stay together when they share dreams, find meaning together, and create a culture of joint rituals and goals, while respecting individual skills.

Likewise, in HR each role has unique expertise (service centers with technology-driven efficiency, centers of expertise with specialized HR insights, embedded HR with business insights). The challenge is to find a unifying purpose that brings together these different parts into a greater whole. This binding purpose may be business performance (strategic HR) or improving customer or investor value (outside-in HR). Each component of HR operations contributes unique value to serving customers, improving market value, and delivering business results.

\section{Respect differences}

In couple therapy, each partner is encouraged to identify and appreciate the strengths of their partner. Couples succeed when they communicate more positively than negatively. Gottman found a 5 to 1 ratio of positive to negative comments in successful couples. Others have found in work settings that leaders are more successful with a 3 to 1 positive to negative relationship ratio. Couples also succeed when they know and respond to their partner's 'love maps', or what matters to their partner.

While it might be awkward to talk about 'HR's love maps', the same logic applies. Clearly, different parts of the HR operating model focus on different activities, with HR service centers emphasizing standardized, consistent, and cost-efficient solutions, and embedded HR generalists working to create tailored HR solutions for unique business requirements. Embedded HR professionals define the talent, leadership, and cultural requirements to deliver business goals. Those working in centers of expertise have pride in their deep functional knowledge. Service center HR professionals ensure that the 'trains run on time' (systems do what they should). When these different groups respect each other, focus on what is right more than what is wrong, and yield to the influence of the other, they can form relationships that supersede their separate roles. When differences are respected, dissent becomes a positive not a negative because there is tension without contention, disagreement with being disagreeable, dialogue without demeaning, confront without being confrontational, challenge without condemning. Each of the groups within an HR operating model is a 'partner' because each brings unique value to the overall goals.

\section{Govern, accept, connect}

A large part of relationship success comes from managing expectations. Researchers have found that 65 to $70 \%$ of relationship problems are never 'solved' but 'managed'. Most of 
the problems early in a relationship are worked around (e.g. spending habits, raising children, doing household chores). It is important to solve solvable problems and not obsess about those that seem to persist.

Likewise, in HR, we may falsely assume that relationships among the parts of HR will be congenial and solved. More realistic expectations recognize that the processes used to govern HR will be more important than the solutions. For example, managing decision rights is less about who makes a decision and more about a process for who makes a decision because the decision right may vary over time. When different parts of an HR operating function can focus on creating a growth mindset, they worry less about the right answer and more about learning to negotiate and discuss. Managing differences with calmness, curiosity, and caring will help build connection among HR parts.

\section{Care for the other}

In relationship therapy, the most important questions that solidify a relationship are: Can I rely on you? Are you safe? Will you be there for me when I need you? Without positive answers to these questions, relationships will crumble under pressure. With positive answers, partners build trust and delight in and celebrate others' success.

In HR departments, it is important that different parts of the operating model care for each other. There needs to be confidence that HR transaction work will be done on time and accurately. Centers of expertise need to be trusted that they will not impose answers, but collaborate to discover innovative solutions. Embedded HR professions need to be able to accurately diagnose current and future business problems. Trust in the HR function should be high due to each area being predictable, dependable, available, accessible, and reliable. Different groups should be aware of scorecards for each group and be delighted when those in other groups do well. 'We' language should replace 'my' language as the metaphor is for HR unity more than isolation.

\section{Share experiences together}

In any relationship, things go wrong. A partner has personal or professional disappointments or a couple has stresses which pull the partners apart. To build stronger personal relationships, partners are encouraged to turn to each other in times of difficulty, to yield to the influence of their partner, to make bids to each other (in successful relationships over $80 \%$ of the bids are responded to), and to be emotionally vulnerable to share deeper feelings with each other. Spending time together and investing emotionally in each other strengthens relationships.

In the HR operating model, it is easy to isolate oneself in one's group. It is more helpful to have individuals work across groups. This may mean career rotation from COEs to embedded HR roles and vice versa, group HR meetings or calls where the groups share concerns and celebrate successes, problem-solving groups with representatives from each HR group, or informal contacts where HR bids are quickly attended to. In addition, when things go wrong in the HR operating model, and they will, rather than blame, complain, or hide, have the emotional confidence to admit a problem and seek a joint solution. 
Grow together

Anyone in a successful relationship over 5 or 10 years can look back to see progress. Relationships morph and each partner in the relationship learns and grows. Some of this growth comes from constantly learning, from focusing on the future and what can be, from letting go of grievances, recognizing vicious cycles and breaking them. Couples with positive relationships recognize growth looking backward and anticipate future growth looking forward.

HR departments need to learn from the past. The stories of HR success can be woven together into an historical narrative of how an HR department has made progress. Sometimes, HR groups don't recognize the progress they have made. But their historical narrative should be a basis for future growth. When the growth of the HR department focuses on the shared purpose of delivering sustainable business value, when differences are respected, when governance is managed, when caring occurs, and when HR professionals share time and energy, then the growth will likely be sustained.

So, for the HR operating model to deliver real value, HR roles matter. Families need houses with rooms that reflect their lifestyle. But relationships matter even more. A nice house will not ensure a well functioning family, nor will an elegant organization chart guarantee an effective HR operating model. Roles matter, but they matter less than relationships. Maybe it is time for our discussions of the HR operating model to focus more on relationships than roles.

\section{HR competencies for HR professionals}

HR professionals also need to up their game to deliver value in today's business setting. This means that HR professionals need to build relationships of trust with business leaders through being credible activists who are trusted because of personal relationship and who take strong positions to build business success. These HR professionals must not only know the business, but be able to strategically position the business. They must master the processes of individual and institutional change. They must be knowledgeable in the science and art of HR. And, they must use information to inform decision-making. When they master this knowledge, skill, and ability, they can deliver the talent, leadership, and capability a business requires to compete in a changing world (Ulrich et al. 2012, 2015).

In our competency research, we found that effective HR professionals function in six roles, as follows (Ulrich et al. 2012).

\section{Strategic positioner}

High-performing HR professionals think and act from the outside/in by mastering four levels of business. First, they learn the language of the business, which revolves around finance. Like as when learning a foreign language, they may not speak like a native, but they need to be able to get around. Second, they need to participate actively and thoughtfully in helping to co-create their organizations' strategy. Third, they need to target and serve key customers of their organization by identifying customer segments, knowing 
customer expectations, and aligning organization actions to meet customer needs. Finally, they need to be deeply knowledgeable of general business conditions (e.g. social, technological, economic, political, environmental, and demographic trends) that affect their respective industries and geographical regions. Strategic positioners go beyond knowing the business to being able to create and shape a business. They do HR from the outside in by anticipating business conditions and building HR practices to respond. A children's hospital includes parents of patients in screening staff; a learning center includes customers as participants and presenters in leadership training; and a senior team doing 360 shifts to 720 as they also get data from those outside the organization.

\section{Credible activist}

Effective HR professionals are credible activists because they build their personal trust by meeting commitments, building relationships, and growing in business acumen (Ulrich, Brockbank and Ulrich 2010). Credibility comes when HR professionals do what they promise, build personal relationships of trust, and can be relied on. Trust comes through personal relationships that endure. They communicate clear and consistent messages with integrity. As activists, HR professionals have a point of view, not only about HR activities, but about business demands. They learn how to influence others in a positive way through clear, consistent, and high-impact communications. Finally, HR professionals need to be self-aware and committed to building their profession.

\section{Capability builder}

An effective HR professional melds individual abilities into effective organization capabilities. As discussed above, capability represents what the organization is good at and known for that represents an organization's institutional strengths and the reputation that the organization has relative to those strengths. Capabilities have been referred to as a company's culture, process, or identity. HR professionals should facilitate capability audits to determine the identity of the organization.

\section{Change champion}

As change champions, HR professionals make sure that isolated and independent organization actions are integrated and sustained through disciplined change processes. HR professionals make an organization's internal capacity for change match or lead the external pace of change. As change champions, HR professionals help make change happen at institutional (changing patterns), initiative (making things happen), and individual (enabling personal change) levels. To make change happen at these three levels, HR professionals play two critical roles in the change process. First, they initiate change by building a case for why change matters, overcoming resistance to change, engaging key stakeholders in the process of change, and articulating the decisions to start change. Second, they sustain change by institutionalizing change through ensuring organizational resources, designing organization structures, facilitating systemic communications, and orchestrating continual learning. Our research found that HR professionals are better at initiating 
change than sustaining change, but the ability to sustain change has more impact on business results. HR often starts more initiatives than they complete.

\section{Human resource innovator and integrator}

Effective HR professionals know the historical research on HR so that they can innovative and integrate HR practices into unified solutions to solve current and future business problems. They must know the latest insights and innovative developments on key HR practice areas related to human capital (talent sourcing, talent development), performance accountability (appraisal, rewards), organization design (teamwork, organization development), and communication. They must also be able to turn these unique HR practice areas into integrated solutions, generally around an organization's leadership brand. These innovative and integrated HR practices then result in high impact on business results by ensuring that HR professionals maintain their focus over the long run and do not become seduced by HR 'flavor the month' or by another firm's 'best practices'.

\section{Technology proponent}

In recent years, technology has changed the way in which HR people think and do their administrative and strategic work. At a basic level, HR professionals need to use technology to more efficiently deliver HR administrative systems such as benefits, payroll processing, healthcare costs, and other administrative services. In addition, HR professionals need to use technology to help people stay connected with each other. This means that technology plays an increasingly important role in improving communications, doing administrative work more efficiently, and connecting inside employees to outside customers. For example, leveraging social media enables the business to position itself for future growth. HR professionals who understand technology will create improved organizational identity outside the company and improve social relationships inside the company. As technology exponents, HR professionals have to access, advocate, analyze and align technology for information, efficiency, and relationships.

\section{Conclusion: HR crossroads}

This paper lays out the content and process crossroads facing HR, requiring HR professionals be architects and anthropologists; scientists and artists; strategic and operational. It also proposes three outcomes of HR, particularly with an outside-in perspective: talent (competence, commitment, and contribution), organization capability and culture, and leadership. And, we propose governing HR through relationships more than roles with the right competencies.

For Asian organizations, this crossroads has particular relevance. Asia leads the world in economic growth with emerging markets in nearly every country. As these countries invest in and innovate their HR capabilities, they may also take the right path on this HR crossroads. Asian HR organizations should rise to the challenges to create even more value through dynamic and disciplined HR processes that create talent, leadership, and 
culture in ways that create market value. This may require updating HR organizations and competencies so that HR fulfills its emerging opportunities.

Without a doubt, the opportunities for HR to have real impact are greater then ever. Hopefully, with the right perspective, outcomes, and transformation, HR will fulfill its promises.

Dave Ulrich is the Rensis Likert Professor of Business at the University of Michigan and partner of The RBL Group. He has written over 30 books, hundreds of articles on human resources, leadership, and organization related issues. He has received numerous lifetime achievement awards and honors. Mostly, he is committed to personal learning.

\section{References}

Allen J and D Ulrich (2013) Talent accelerator: Secrets for driving business growth in Asia. RBL Group and Ministry of Manpower, Singapore.

Bassi L, D Creelman and A Lambert (2014) The smarter annual report: How companies are integrating financial and human capital reporting. Creelman Lambert and McBassi \& Company.

Chakrabarti A, K Singh and I Mahmood (2007) Diversification and performance, evidence from East Asian firms. Strategic Management Journal 28(2), 101-120.

The Conference Board (2014) CEO challenge. www.ceochallenge.org

de Waal A and C Tan Akaraboworn (2013) Is the high performance organization framework suitable for Thai organizations. Measuring Business Excellence 17(4), 76-87.

Danish RQ and A Usman (2010) Impact of reward and recognition on job satisfaction and motivation: An empirical study from Pakistan. International Journal of Business and Management 5,159 .

Gladwell M (2011) Outliers: The story of success. Back Bay Books, New York.

Lawler E and J Boudreau (2015) Global trends in human resource management: A twenty year analysis. Stanford University Press, Palo Alto, CA.

Michaels E, H Handfield-Jones and B Axelrod (2001) The war for talent. Harvard Business School Press, Boston, MA.

Nankervis A, S Chatterjee, F Cooke and M Warner (2013) New models of HRM in China \& India. Routledge, London and New York.

Michaels E, H Handfield-Jones and B Axelrod (2001) The war for talent. Harvard Business School Press, Boston, MA.

Osman I, TC Ho and M Galang (2011) The relationship between human resource practices and firm performance: An empirical assessment of firms in Malaysia. Business Strategy Series 12, $41-48$.

Rowley C, J Benson and M Warner (2004) Towards an Asian model of human resource management? A comparative analysis of Japan and Korea. International Journal of Human Resource Management 15(4-5), 917-933.

Rowley C and G Redding (2012) Building human and social capital in Pacific Asia. Asia Pacific Business Review 18(3), 1-7.

Rowley C and D Ulrich (2012) Setting the scene for leadership in Asia. Asia Pacific Business Review 18(4), 451-464. 
Rowley C and D Ulrich (2013) Leadership in the Asia Pacific: A global research perspective. Routledge, London.

Treverton G (2003) Reshaping national intelligence for an age of information. Cambridge University Press, Cambridge, UK.

Ulrich D (1997) What is organization? Leader to Leader 5, 40-46.

Ulrich D (1998) Intellectual capital = Competence * commitment. Sloan Management Review 39(2), $15-26$.

Ulrich D (2015a) Leadership capital index: Realizing the market value of leadership. Berrett Kohler, San Francisco, CA.

Ulrich D (2015b) Leadership capital index: The market value of leadership. Berrett-Kohler, San Francisco, CA.

Ulrich D (2015c) The future of HR is about relationships. www.cipd.co.uk/pm/peoplemanagement/ b/weblog/archive/2015/03/24/the-future-of-hr-is-about-relationships.aspx

Ulrich D (ed) (2010) Leadership in Asia: Challenges and opportunities. McGraw Hill, Singapore.

Ulrich D, J Allen, N Smallwood, N Brockbank and J Younger (2009) Building culture from the outside in. Strategic HR Review 8(6), 20-27. [Note that these six competencies are from the 2012 (Round 6) HR competence research and there are emerging results from 2016 (Round 7), yet to be published.]

Ulrich D, W Brockbank and M Ulrich (2010) Capturing the credible activist to improve performance of HR professionals. People and Strategy 33(2), 22-30.

Ulrich D, W Brockbank, M Ulrich and D Kryscynski (2015) Toward a synthesis of HR competency models: The common HR 'food groups'. People and Strategy 38(4), 56-64.

Ulrich D, W Brockbank, J Younger and M Ulrich (2012) Global HR competencies: Mastering competitive value from the outside-in. McGraw-Hill, New York.

Ulrich D and J Dulebohn (2015) Are we there yet? What's next for HR? Human Resource Management Review 25, 188-204.

Ulrich D and E Filler (2015) CEOs and CHROs: Expectations, connections, and succession. Skills to build robust and resilient organizations. Leader to Leader 2015, 33-41.

Ulrich D and J Grochowski (2012) From shared services to professional services. Strategic HR Review 11(3), 136-142.

Ulrich D and N Smallwood (2004) Capitalizing on capabilities. Harvard Business Review 2004, 119 128.

Ulrich D and R Sutton (2011) Asian leadership: What works. McGraw Hill, Singapore.

Ulrich D and W Ulrich (2011) Why of work: Creating the abundant organization. McGraw Hill, New York.

Ulrich D, J Younger and W Brockbank (2008) The 21st century HR organization. Human Resource Management 47(4), 829-850.

Ulrich D, J Younger, W Brockbank and M Ulrich (2012) HR from the outside in: Six competencies for the future of human resources. McGraw-Hill, New York.

Yeung A and D Ulrich (1990) Effective human resource practices for competitive advantages: An empirical assessment of organizations in transition. In RJ Niehaus and KF Price (eds) Human resource strategies for organizations in transition, 311-326. Plenum Publishing Company, New York.

Yeung A, M Warner and C Rowley (2008) Guest editors' introduction: Growth and globalization Evolution of HRM practices in Asia. Human Resource Management 47(1), 1-13. 